\title{
Application of the Lewis Acid-Lewis Base Bifunctional Asymmetric Catalysts to Pharmaceutical Syntheses: Stereoselective Chiral Building Block Syntheses of Human Immunodeficiency Virus (HIV) Protease Inhibitor and $\boldsymbol{\beta}_{3}$-Adenergic Receptor Agonist
}

\author{
Hiroyuki Nogami, ${ }^{*}, a$ Motomu KanaI, ${ }^{b}$ and Masakatsu ShiBASAKI ${ }^{b}$ \\ ${ }^{a}$ Chemicals Development Laboratories, Mitsubishi Rayon Co., Ltd.; Daikoku-cho, Tsurumi-ku, Yokohama, Kanagawa \\ 230-0053, Japan: and ${ }^{b}$ Graduate School of Pharmaceutical Sciences, The University of Tokyo; Hongo, Bunkyo-ku, Tokyo \\ 113-0033, Japan. Received March 10, 2003; accepted March 20, 2003
}

\begin{abstract}
Chiral building block syntheses of promising drugs were achieved using two types of catalytic stereoselective cyanosilylations of aldehydes promoted by Lewis acid-Lewis base bifunctional catalysts 1 and 2 as the key steps (diastereoselective cyanosilylation of amino aldehyde and enantioselective cyanosilylation). In the first part of this article, syntheses of chiral building blocks (6) of Atazanavir (3: human immunodeficiency virus (HIV) protease inhibitor) using the bifunctional catalyst 2 are discussed. The reaction of Boc-protected phenylalaninal 21 in the presence of $1 \mathrm{~mol} \%$ catalyst 2 selectively afforded the anti isomer 22 as the major product (diastereomeric ratio $=97: 3$ ), which was successively converted to the corresponding epoxide 6 in six steps. In the second part, we describe a chiral building block synthesis of $\beta_{3}$-adrenergic receptor agonists. The enantioselective cyanosilylation of 3-chlorobenzaldehyde (38) with 9 mol\% catalyst 1 gave the chiral cyanohydrin 39, which was converted to $\beta$ hydroxyethylamine 40 by reduction. Moreover, the chiral ligand of catalyst 1 could be recovered without column chromatography and reused without decreasing its activity.
\end{abstract}

Key words bifunctional asymmetric catalyst; cyanosilylation; asymmetric catalysis; human immunodeficiency virus (HIV) protease inhibitor; $\beta_{3}$ adrenergic receptor agonist

The synthesis of optically pure compounds is important in the development of pharmaceuticals, agrochemicals, and their intermediates. ${ }^{1-4)}$ Catalytic asymmetric reaction is an ambitious and powerful method for the synthesis of chiral compounds in terms of atom economy. Therefore, the development of new enantioselective catalysts has been extensively investigated. ${ }^{5-7)}$ We recently succeeded in developing chiral bifunctional catalysts $\mathbf{1}^{8-11)}$ and $\mathbf{2}^{12,13)}$ based on the concept of bifunctional catalysis (Fig. 1). Based on mechanism studies, such as IR studies, kinetic profiles, and absolute configuration of the products, the catalysts promote the cyanosilylation reaction via a simultaneous dual activation of the substrate by the Lewis acid (aluminum metal) and the Lewis base (oxygen atom of the phosphine oxide) at defined positions in the transition state. This dual activation mechanism affords high stereoselectivity from a wide variety of substrates.

Cyanohydrins are highly versatile intermediates that can be easily converted into important chiral building blocks, including $\alpha$-hydroxy carbonyl derivatives, $\beta$-hydroxyethylamine, $\alpha$-amino acids, etc. ${ }^{14-20)}$ Catalyst 1 promotes the catalytic asymmetric cyanosilylation of various aldehydes ${ }^{8-11}$ as well as of imines ${ }^{21,22)}$ with high enantioselectivity and substrate generality. On the other hand, catalyst $\mathbf{2}$ is applied to the asymmetric addition of TMSCN to aldehydes and acetophenone, ${ }^{12)}$ and can also efficiently promote a variety of catalytic diastereoselective cyanosilylations of aminoaldehydes with excellent stereoselectivity. ${ }^{13)}$ Because enantioselective cyanosilylation is a key step in the synthesis of important intermediates of many pharmaceuticals, catalysts $\mathbf{1}$ and $\mathbf{2}$ are very useful. We previously demonstrated the synthesis of several biologically significant compounds using catalytic enantioselective cyanosilylation promoted by these catalysts, as a key step. ${ }^{23-29)}$ Herein, we report that catalysts $\mathbf{1}$ and $\mathbf{2}$ are highly efficient for the asymmetric synthesis of chiral building blocks of an human immunodeficiency virus (HIV) protease inhibitor (Atazanavir) and a $\beta_{3}$-adrenergic receptor agonist.

\section{Results and Discussion}

Building Block Syntheses of Atazanavir ${ }^{30-33)}$ Atazanavir (3) is an azapeptide HIV-1 protease inhibitor class and is currently in phase III clinical trials (Fig. 2). ${ }^{34,35)}$ Fässler et al. reported that Atazanavir is obtained using four fragments (tert-leucine-derivative $\mathbf{4}$, amino epoxide $\mathbf{6}$, biaryl compound $\mathbf{8}$, and hydrazine 9). ${ }^{31}$ Thus, first, biaryl compound $\mathbf{8}$ was synthesized using a nickel(II)-catalyzed $\mathrm{Ku}-$ mada reaction of the Grignard reagent prepared from 4-bromobenzaldehyde dimethyl acetal and 2-bromopyridine, followed by acidic hydrolysis. Next, the reaction of $\mathbf{8}$ with hydrazine 9 afforded hydrazone, which was reduced to hydrazine 7. Condensation of 7 with amino epoxide 6 and full deprotection resulted in the addition product $\mathbf{5}$. Finally, $\mathbf{5}$ was condensed with tert-leucine derivative $\mathbf{4}$ to give Atazanavir.

Of the above fragments, we previously reported that tertleucine could be synthesized by an enantioselective Streckertype reaction as a key step in the presence of $9 \mathrm{~mol} \%$ of catalyst 1 and $20 \mathrm{~mol} \%$ of $\mathrm{PhOH}$ as a proton source. ${ }^{21,22,36)}$ This time, we expected that the amino epoxide 6 would be ob-

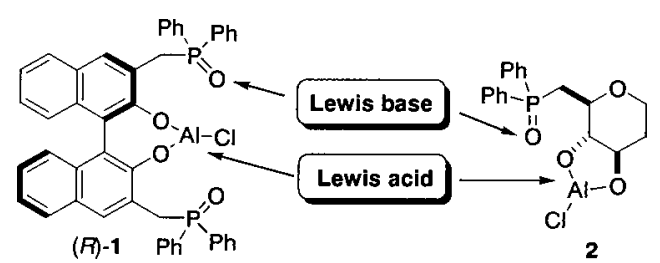

Fig. 1

C 2003 Pharmaceutical Society of Japan 


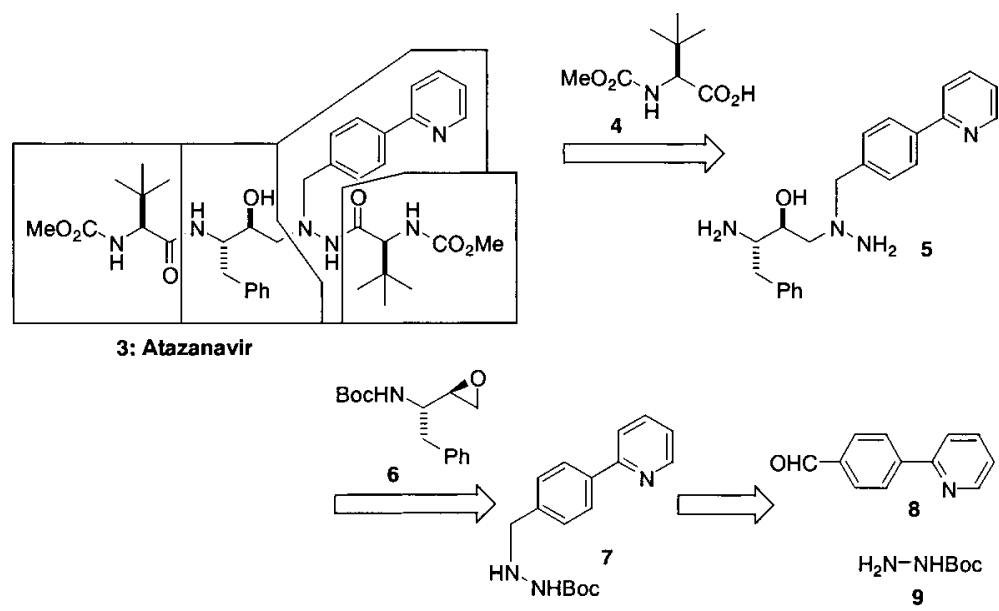

Fig. 2
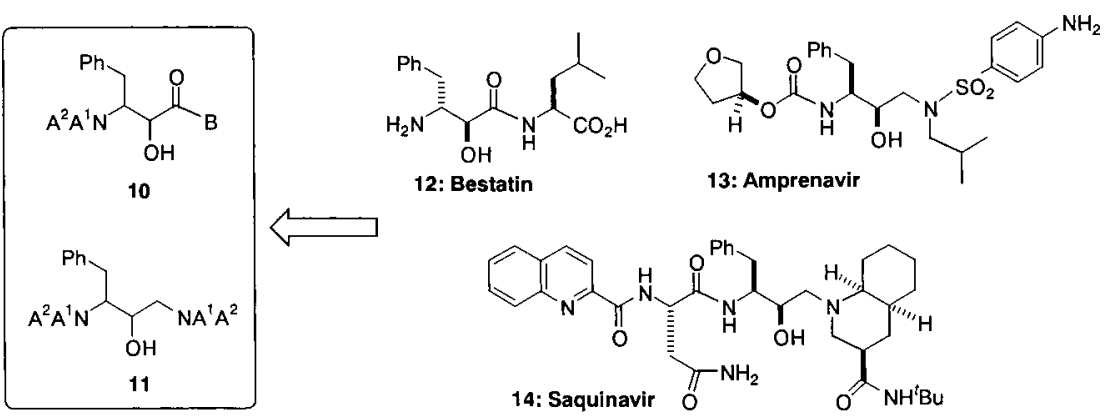

Fig. 3
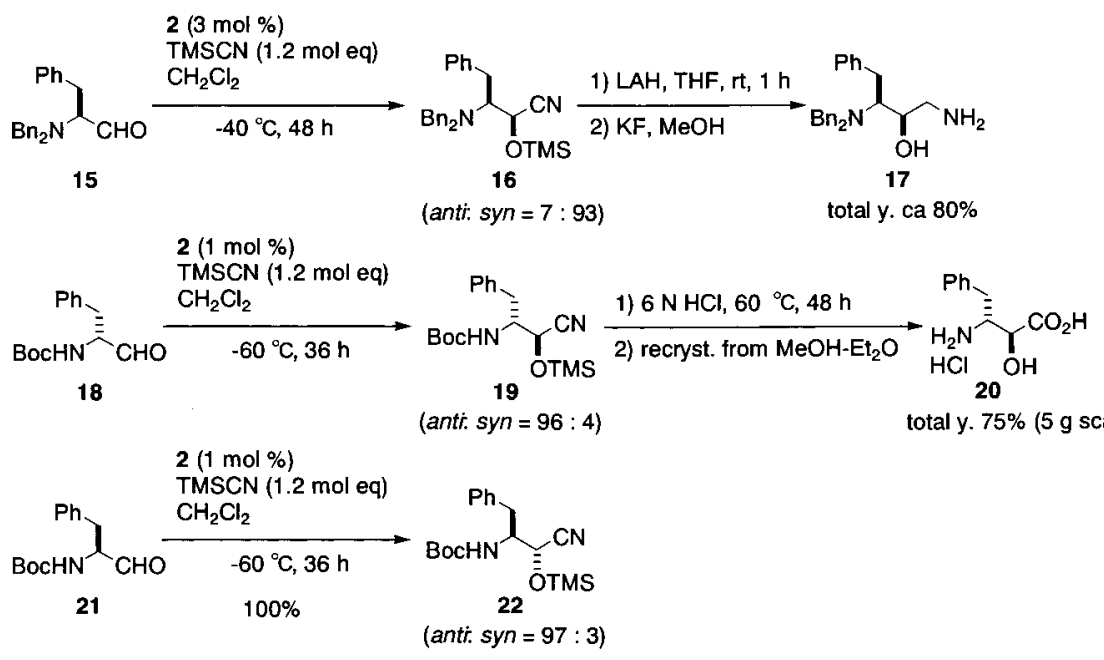

Chart 1

tained via asymmetric cyanosilylation of aminoaldehyde using bifunctional catalyst $\mathbf{2}$, and biaryl $\mathbf{8}$ would be synthesized via a one-step Suzuki-Miyaura reaction. Thus, we planned to synthesize these fragments of Atazanavir.

The Chiral Amino Epoxide (6) ${ }^{37-40)}$ Pseudopeptides, containing 3-amino-2-hydroxycarboxylic acids $\mathbf{1 0}$ or 3amino-2-hydroxyamines $\mathbf{1 1}$, are essential components in many medicinally important compounds (Fig. 3). For example, Bestatin (12) is an aminopeptidase inhibitor that exhibits immunostimulatory as well as cytotoxic activity and is used clinically as an anticancer agent. ${ }^{41-48)}$ On the other hand,
Amprenavir (13) $)^{49)}$ and Saquinavir $(\mathbf{1 4})^{50,51)}$ are therapeutically useful HIV protease inhibitors. ${ }^{52-56)}$

For synthesis of the essential chiral building blocks of these compounds, considerable research effort has been directed towards the diastereoselective cyanation of chiral amino aldehydes. ${ }^{57-59)}$ A stoichiometric or excess amount of promoters or reagents, however, is usually used, and the diastereoselectivity is not always high. Therefore, we investigated the cyanosilylation of $N$-protected chiral aminoaldehydes in the presence of bifunctional catalyst 2 instead of achiral promoters, and succeeded in the anti- and syn-selective 

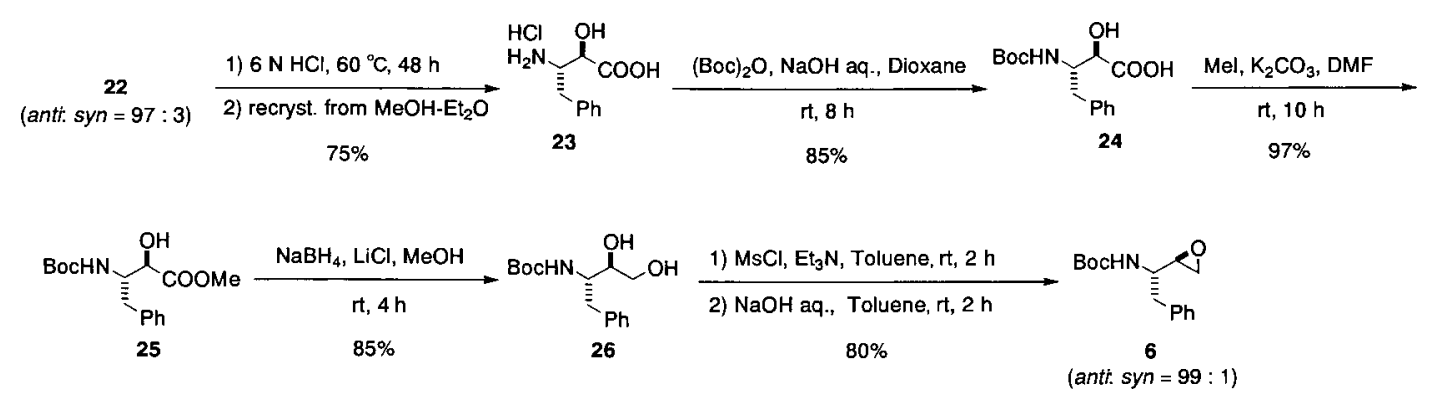

Chart 2

cyanosilylation reactions with excellent yield and high diastereoselectivity (Chart 1). ${ }^{13)}$ For example, the syn isomer 16 (93\% yield, diastereomeric ratio; anti $:$ syn $=7: 93)$ was obtained as the major product using dibenzyl protected Lphenylalaninal $15 .{ }^{60)}$ In addition, the anti isomer $19(100 \%$ yield, diastereomeric ratio; anti: $s y n=96: 4$ ) was obtained in the case of Boc-protected L-phenylalaninal 18. Also, the anti isomer $22(100 \%$ yield, diastereomeric ratio; anti $: s y n=$ $97: 3)$ was obtained from the Boc-protected D-aminoaldehyde 21.

Using syn- and anti-selective cyanosilylations, effective syntheses of some useful chiral building blocks were achieved. One was a short-step synthesis of Corey's intermediate of Amprenavir 13. ${ }^{49}$ The other was a practical synthesis of the important building block of Bestatin 12, achieved in 5 -g scale.

These initial promising results led us to attempt the synthesis of a pharmaceutically important intermediate $\mathbf{6}$ from 22 as follows (Chart 2). Acid hydrolysis of 22 with $6 \mathrm{~N} \mathrm{HCl}$ followed by recrystallization from $\mathrm{MeOH}-\mathrm{Et}_{2} \mathrm{O}$ gave the diastereomerically pure $\beta$-amino- $\alpha$-hydroxy acid $\mathbf{2 3}{ }^{61,62)} \mathrm{Com}$ pound 23 was protected with $(\mathrm{Boc})_{2} \mathrm{O}$ to give compound 24, ${ }^{63-65)}$ which was esterified with $\mathrm{MeI}-\mathrm{K}_{2} \mathrm{CO}_{3}$ to compound 25. ${ }^{63)}$ Then, the ester group was reduced with $\mathrm{NaBH}_{4}-\mathrm{LiCl}$ to give diol 26. ${ }^{40,66)}$ Selective mesylation of $\mathbf{2 6}$ followed by subsequent intramolecular cyclization gave the expected epoxide 6. The diastereomeric ratio remained high (anti $: \operatorname{syn}=99: 1)$ through six steps.

2-(4-Formylphenyl)pyridine (8) Classic biaryl coupling procedures (e.g., Ullmann reaction, or Grignard reaction) often lack selectivity or give moderate yields. Keeping in mind the compatibility with reactive functionality and the toxicity of the reagent, a transition-metal-catalyzed cross coupling between an electrophile (e.g., aryl halide and pseudo aryl halide) and an organoborane in the presence of an aqueous base, the so-called Suzuki-Miyaura reaction, is one of the most efficient and versatile tools for the synthesis of biaryls. ${ }^{67-69)}$ Aryl bromide, iodide, and triflate are efficiently activated by a palladium complex, and are therefore often employed for the Suzuki-Miyaura reaction. On the other hand, aryl chloride substrates are less reactive but more attractive than the corresponding bromide, iodide, and triflate because they are readily available and inexpensive. Nickelcomplexes often have higher reactivity toward aryl chloride than palladium-complexes, thus we elaborated the cross-coupling reaction of 2-chloropyridine (27) with 4-formylboronic acid (28) for the synthesis of $\mathbf{8}$ in our first approach (Table $1)$.

The reaction, unfortunately, did not take place at all (Table
Table 1. Synthesis of Biaryl Compound $\mathbf{8}$

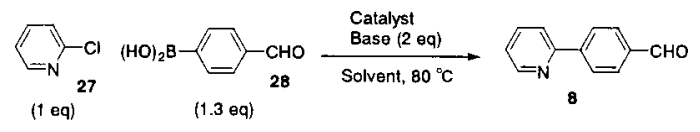

\begin{tabular}{clllrr}
\hline \hline Entry & \multicolumn{1}{c}{$\begin{array}{c}\text { Catalyst } \\
(\mathrm{mol} \%)\end{array}$} & Solvent & Base & \multicolumn{1}{c}{$\begin{array}{c}\text { Time } \\
(\mathrm{h})\end{array}$} & $\begin{array}{c}\text { Yield } \\
(\%)\end{array}$ \\
\hline 1 & $\mathrm{Ni}\left(\mathrm{PPh}_{3}\right)_{n}(3)$ & $\mathrm{DME}$ & $\mathrm{LiOH}$ & 15 & 0 \\
2 & $\mathrm{NiCl}_{2}\left(\mathrm{PPh}_{3}\right)_{2}(3)$ & $\mathrm{DME}$ & $\mathrm{Na}_{2} \mathrm{CO}_{3}$ & 15 & 0 \\
3 & $\mathrm{NiCl}_{2}\left(\mathrm{PPh}_{3}\right)_{2}(3)$ & $\mathrm{DME}$ & $\mathrm{K}_{3} \mathrm{PO}_{4}$ & 15 & 0 \\
4 & $\mathrm{NiCl}_{2}\left(\mathrm{PPh}_{3}\right)_{2}(3), \mathrm{PPh}_{3}(15)$ & $\mathrm{DME}$ & $\mathrm{K}_{3} \mathrm{PO}_{4}$ & 15 & 20 \\
5 & $\mathrm{Ni}_{(\mathrm{dppf}) \mathrm{Cl}_{2}(3),{ }^{n} \mathrm{BuLi}(12)}$ & $\mathrm{DME}$ & $\mathrm{K}_{3} \mathrm{PO}_{4}$ & 15 & 32 \\
6 & $\mathrm{PdCl}_{2}(\mathrm{cod})(3)$ & $\mathrm{DME}-\mathrm{H}_{2} \mathrm{O}$ & $\mathrm{Na}_{2} \mathrm{CO}_{3}$ & 7 & 55 \\
7 & $\mathrm{Pd}\left(\mathrm{PPh}_{3}\right)_{4}(3)$ & $\mathrm{DME}-\mathrm{H}_{2} \mathrm{O}$ & $\mathrm{Na}_{2} \mathrm{CO}_{3}$ & 10 & 96 \\
8 & $\mathrm{Pd}\left(\mathrm{PPh}_{3}\right)_{4}(0.3)$ & $\mathrm{DME}-\mathrm{H}_{2} \mathrm{O}$ & $\mathrm{Na}_{2} \mathrm{CO}_{3}$ & 12 & 92 \\
\hline
\end{tabular}

a) Isolated yield.

1, entry $1-3)^{70)}$ Excess addition of $\mathrm{PPh}_{3}$ to $\mathrm{NiCl}_{2}$ improved the reaction little (Table 1 , entry 4$)^{71)}$ The nickel complex (0), prepared in situ by treating the nickel chloride with ${ }^{n} \mathrm{BuLi}$ at room temperature, resulted in $32 \%$ yield (Table 1 , entry 5) ${ }^{72)}$ Although the reason is not clear, these results suggest that 2-chloropyridine (27) is strongly resistant to nickel-catalyzed coupling. ${ }^{73)}$

Next, we investigated the cross coupling reaction using a palladium-complex, which is often a superior catalyst for certain aryl chlorides. ${ }^{74-76)}$ The coupling reaction resulted in a slightly reduced yield in the presence of $3 \mathrm{~mol} \%$ $\mathrm{PdCl}_{2}$ (cod) (Table 1, entry 6). When the mixture was heated to $80^{\circ} \mathrm{C}$ for $10 \mathrm{~h}$ using $3 \mathrm{~mol} \% \mathrm{Pd}\left(\mathrm{PPh}_{3}\right)_{4}$ under basic conditions, however, the target compound $\mathbf{8}$, accompanied by less than $1 \%$ of the homo-coupling product, was obtained in $96 \%$ yield. Also, a small amount of the homo-coupling product was also completely separated after simple acidic extraction. Moreover, the reaction was also completed using $0.3 \mathrm{~mol} \%$ $\mathrm{Pd}\left(\mathrm{PPh}_{3}\right)_{4}$ in $12 \mathrm{~h}$ (Table 1, entry 8).

As described above, we successfully prepared the three fragments $(4,6,8)$ using two types of catalytic stereoselective cyanosilylations promoted by Lewis acid-Lewis base bifunctional catalysts and the Suzuki-Miyaura reaction. These reactions are practical, and thus can be applied to a large scale synthesis of Atazanavir.

(2R)-2-(3-Chlorophenyl)-2-hydroxyethylamine

Obesity causes significant complications such as type 2 diabetes mellitus, high blood pressure, coronary heart disease, and hyperlipidemia. ${ }^{77)}$ Recently, the $\beta_{3}$-adrenergic receptor (AR) was isolated and characterized as the third $\beta$ AR subtype $^{78)} \beta_{3}$ AR is suggested to have a significant role in the 


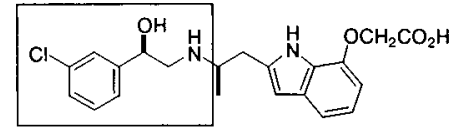

29: AJ-9677

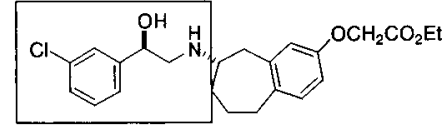

30: FR-149175
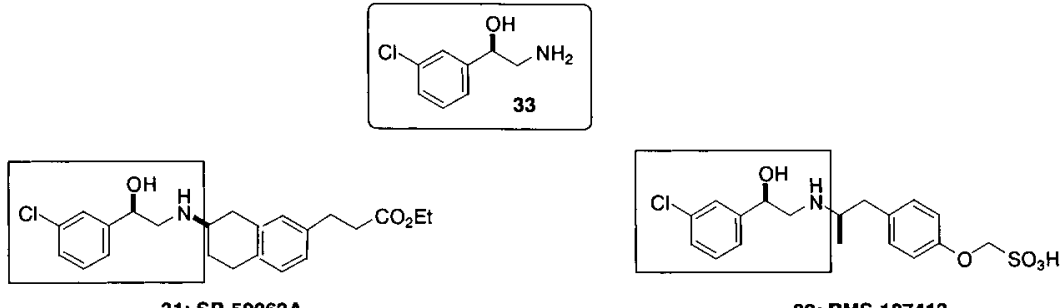

32: BMS-187413

Fig. 4

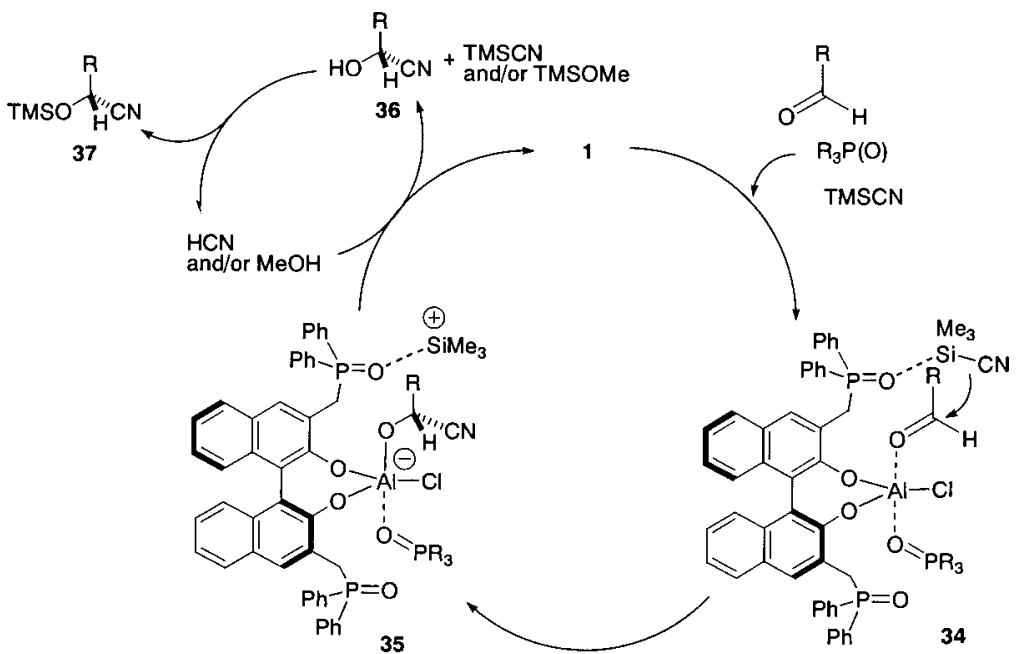

Fig. 5

control of lipolysis and thermogenesis in brown adipose tissue of rodents and humans. Thus, $\beta_{3}$ AR-stimulating agents have attracted attention for the treatment of obesity and type 2 diabetes. ${ }^{79)}$ On the other hand, $\beta_{1}$ AR-stimulating drugs are clinically used as a cardiac function promoter or vasopressor, and $\beta_{2}$ AR-stimulating drugs are used as bronchodilators. The structural similarity of $\beta_{3}$ AR to known $\beta$ AR agonists has led to studis to develop a drug with selective $\beta_{3}$ AR agonist activity. There are currently many compounds with this type of activity, such as AJ-9677 (29), FR-149175 (30), SR59062A (31), and BMS-187413 (32) (Fig. 4). ${ }^{79)}$

These compounds contain 2-(3-chlorophenyl)-2-hydroxyethylamine (33) as a common chiral building block. Therefore, we focused on the synthesis of this moiety via a catalytic asymmetric cyanosilylation of 3-chlorobenzaldehyde (38) using the bifunctional catalyst $(S)-\mathbf{1}$.

First, we attempted a catalytic asymmetric cyanosilylation of $38(30 \mathrm{mg}$ scale $)$ at $-40{ }^{\circ} \mathrm{C}$ for $96 \mathrm{~h}$ in the presence of $9 \mathrm{~mol} \%$ of the catalyst $(S)-\mathbf{1}$, and the product 39 was obtained in $98 \%$ yield with $80 \%$ ee (Table 2 , entry 1 ). When this catalytic asymmetric cyanosilylation was applied to a larger scale reaction $(60 \mathrm{mg}$ scale), however, the reaction rate was retarded. Intensive investigation indicated that the addition of a catalytic amount of a proton source $(\mathrm{MeOH})$ had an important role in reproducing the results of the smaller scale reactions (Table 2 , entry 4 ).
Table 2. Catalytic Asymmetric Cyanosilylation of 3-Chlorobenzaldehyde 38

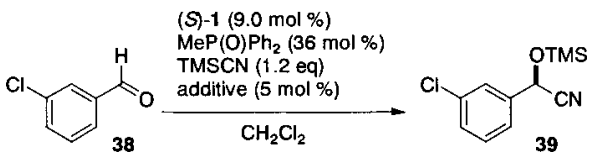

\begin{tabular}{cccccc}
\hline \hline Entry & Additive & Temp $\left({ }^{\circ} \mathrm{C}\right)$ & Time $(\mathrm{h})$ & Yield $(\%)^{a)}$ & ee $(\%)^{b)}$ \\
\hline 1 & - & -40 & 91 & 82 & 80 \\
2 & - & -30 & 64 & 68 & 80 \\
3 & - & -50 & 64 & 25 & 82 \\
4 & $\mathrm{MeOH}$ & -40 & 72 & 73 & 88 \\
5 & ${ }^{i} \mathrm{PrOH}$ & -40 & 72 & 85 & 86 \\
6 & ${ }^{t} \mathrm{BuOH}$ & -40 & 72 & 70 & 87 \\
7 & $\mathrm{PhOH}$ & -40 & 72 & 72 & 87 \\
8 & $\mathrm{MeOH}$ & -40 & 96 & 98 & $90^{c)}$
\end{tabular}

a) Isolated yield. b) Determined by HPLC analysis after convention to ethyl carbonate. c) TMSCN pre-mixed MeOH was slowly added over $8 \mathrm{~h}$.

A beneficial role of the proton is proposed in Fig. 5. 9,21,22,28) Namely, HCN generated from TMSCN and MeOH should protonate the aluminum alkoxide 35, facilitating regeneration of the active catalyst $1^{80-83)}$ The resulting free cyanohydrin 36 was immediately silylated under the reaction conditions to give the TMS protected form 37. Because HCN should be regenerated from TMSCN and the free cyanohy- 
drin, only a catalytic amount of $\mathrm{MeOH}$ was required for the catalytic cycle.

The kinetic profile of this reaction was investigated to gain further insight into the reaction mechanism using benzaldehyde as a substrate. The reaction at $-40^{\circ} \mathrm{C}$ was monitored by NMR spectroscopy by observing the disappearance of the aldehyde proton. The initial reaction rate was 1.4 times faster in the presence of the proton source than in its absence (Fig. 6).

So, we investigated the effect of different protic sources to improve the yield on a gram scale reaction. $\mathrm{MeOH}$ afforded a higher yield and the highest enantiomeric excesses, although other alcohols gave only slightly lower enantioselectivity (Table 2, entry 5-7). Treatment of 38 with TMSCN premixed with $5 \mathrm{~mol} \%$ of $\mathrm{MeOH}$ in the presence of $9 \mathrm{~mol} \%$ of the catalyst $(S)-1$ at $-40{ }^{\circ} \mathrm{C}$ for $96 \mathrm{~h}$ led to the efficient formation of cyanohydrin 39 in $98 \%$ yield with $88 \%$ ee. There was further improvement when TMSCN pre-mixed with $5 \mathrm{~mol} \%$ of $\mathrm{MeOH}$ was added slowly to the reaction mixture, giving 39 in $98 \%$ yield with $90 \%$ ee (Table 2, entry 8). These results demonstrate that the addition of a catalytic amount of a proton source is very important for this asymmetric induction. Having optimized the reaction conditions, the corresponding cyanohydrin 39 was successfully performed on a gram scale.

Subsequent reduction of TMS-protected cyanohydrin 39 with $\mathrm{BH}_{3} \cdot \mathrm{SMe}_{2}$ provided the expected $\beta$-hydroxyamine 33 . To avoid chromatographic purification, compound $\mathbf{3 3}$ was obtained as a crystalline $\mathrm{HCl}$ salt with $\mathrm{HCl}-\mathrm{MeOH}$ treatment. Recrystallization from $\mathrm{MeOH}-\mathrm{MTBE}$ (methyl tertbutyl ether) afforded the enantiomerically and chemically pure salt 40 (Chart 3).

Recycling of the Catalyst Establishment of a recycling method for asymmetric catalysts (or ligands) is very impor-

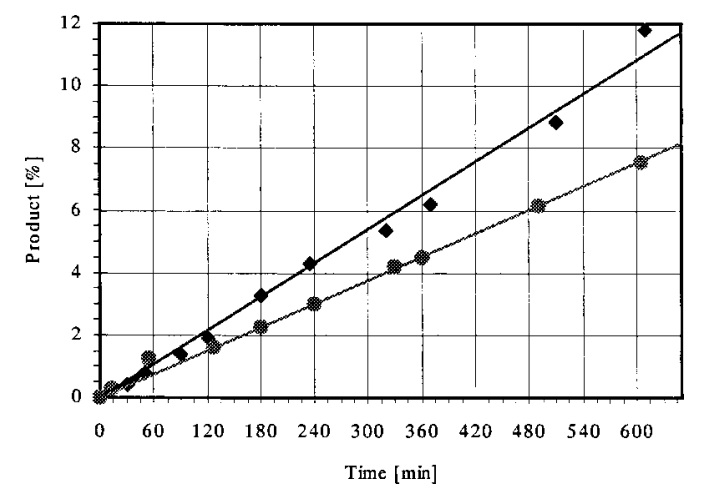

Fig. 6. Initial Reaction Rate of Benzaldehyde in the Absence and in the Presence of $5 \mathrm{~mol} \%$ of $\mathrm{MeOH}$

The disappearance of benzaldehyde was traced by ${ }^{1} \mathrm{H}-\mathrm{NMR}$ : the reaction in the absence $(\bullet)$ and in the presence $(\bullet)$ of $5 \mathrm{~mol} \%$ of $\mathrm{MeOH}$. tant for catalytic asymmetric synthesis in terms of atom economy and the cost of the process. Solid-supported catalysts are very important in terms of easy separation of the product, and the potential to reuse the catalyst in subsequent reactions. Although we developed a recyclable solid-supported catalyst $\mathbf{4 1}$ for an asymmetric Strecker-type reaction (Chart 4), ${ }^{84} \mathbf{4 1}$ did not catalyze the catalytic asymmetric cyanosilylation of aldehydes. Therefore, we developed an alternative method to recover chiral ligand 42 (Fig. 7).

After cyanosilylation was performed, the ligand was recovered as follows. The reaction mixture was quenched by the addition of $\mathrm{HCl}$, and the extracted organic layer, including the product and the ligand, was evaporated. Ether was added to the residue and the slurry was stirred for $1 \mathrm{~h}$ at $0^{\circ} \mathrm{C}$. The precipitation was filtered and the ligand was recovered almost quantitatively. Recrystallization of the recovered ligand from $\mathrm{CH}_{2} \mathrm{Cl}_{2}-\mathrm{Et}_{2} \mathrm{O}$ successfully gave purified ligand $\mathbf{4 2}$ (recovery 96\%). Moreover, 42 could be reused without any loss of activity or enantioselectivity.

\section{Conclusion}

We report the synthesis of some medically important chiral building blocks via stereoselective cyanosilylations using the bifunctional catalysts $\mathbf{1}$ and $\mathbf{2}$. These reactions are practical and were successfully applied to efficient catalytic asymmetric syntheses of chiral building blocks. In addition, we demonstrated that ligand $\mathbf{4 2}$ of catalyst $\mathbf{1}$ can be easily recovered without column chromatography and reused without any loss of the activity or enantioselectivity. These results demonstrate that future pilot scale syntheses of chiral cyanohydrins using catalysts $\mathbf{1}$ and $\mathbf{2}$ might be possible.

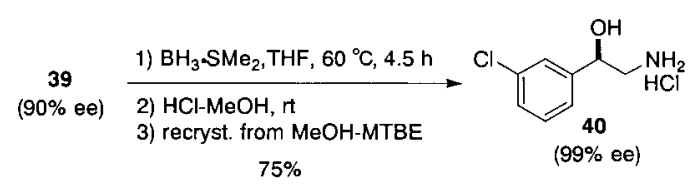

Chart 3
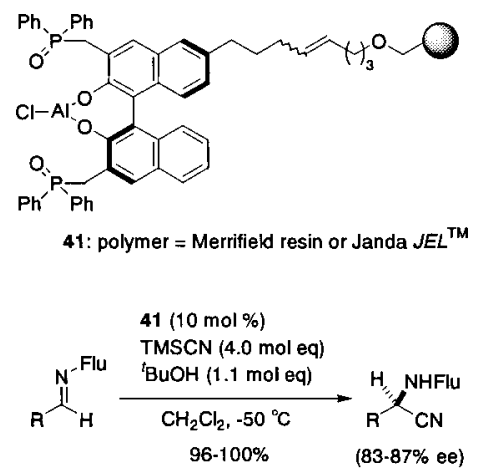

Chart 4

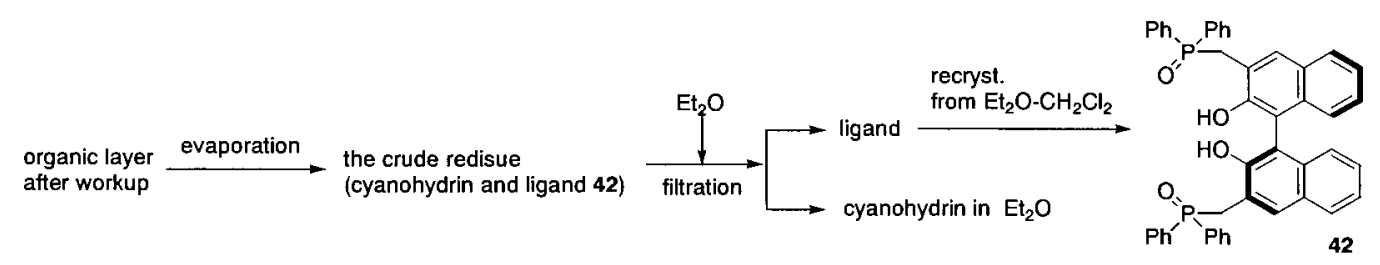

(recyclable!)

Fig. 7. Recycling of the Catalyst 


\section{Experimental}

General Experimental Procedures NMR spectra were recorded on a JEOL GX-270 spectrometer, operating at $270 \mathrm{MHz}$ for ${ }^{1} \mathrm{H}-\mathrm{NMR}$ and $67.5 \mathrm{MHz}$ for ${ }^{13} \mathrm{C}$-NMR. Chemical shifts were reported in ppm on the $\delta$ scale relative to TMS ( $\delta=0.00 \mathrm{ppm}$ for ${ }^{1} \mathrm{H}-\mathrm{NMR}$ ) or using residual $\mathrm{CDCl}_{3}$ ( $\delta=7.24$ for ${ }^{1} \mathrm{H}-\mathrm{NMR}$ and $\delta=77.0$ for $\left.{ }^{13} \mathrm{C}-\mathrm{NMR}\right)$ or $\mathrm{CD}_{3} \mathrm{OD}(\delta=3.30$ for ${ }^{1} \mathrm{H}-\mathrm{NMR}$ and $\delta=49.0$ for ${ }^{13} \mathrm{C}-\mathrm{NMR}$ ) as an internal reference. Infrared (IR) spectra were recorded on a PERKIN ELMER 1600 fourier transform infrared spectrophotometer. EI mass spectra were measured on a HEWLETT PACKARD G1800A GCD system or a JEOL JMS-SX102A system. HR mass spectra were measured on a JEOL JMS-SX102A system. Optical rotations were measured on a HORIBA SEPA-200 polarimeter. Flash column chromatography was performed with silica gel Merck $60(230-400$ mesh ASTM). Enantiomeric excess (ee) was determined by HPLC analysis. HPLC analysis was performed on JASCO HPLC systems consisting of the following: pump, 880-PU; detector, $875-\mathrm{UV}$, measured at $254 \mathrm{~nm}$ or $200 \mathrm{~nm}$; column, Daicel CHIRALCEL OD-H or CROWNPAK CR(+). In general, the reactions were performed in dried solvents under an argon atmosphere, unless noted otherwise. Diethylaluminum chloride in hexane $(0.93 \mathrm{M})$ was purchased from Kanto Chemical Co., Inc., Tokyo. Starting materials were commercially available or synthesized by the reported procedure.

$(2 R, 3 S)-N$-(tert-Butoxycarbonyl)-3-amino-2-trimethylsilyloxy-4phenylbutanenitrile(22) $\quad \mathrm{Et}_{2} \mathrm{AlCl}$ in hexane solution $(0.93 \mathrm{M}, 0.2 \mathrm{mmol})$ was added to a solution of ligand $2(66 \mathrm{mg}, 0.2 \mathrm{mmol})$ in $\mathrm{CH}_{2} \mathrm{Cl}_{2}(3.5 \mathrm{ml})$ at ambient temperature. After $30 \mathrm{~min}$, a solution of aldehyde $21(5.00 \mathrm{~g}$, $20.0 \mathrm{mmol})$ in $\mathrm{CH}_{2} \mathrm{Cl}_{2}(50 \mathrm{ml})$ and TMSCN $(3.2 \mathrm{ml}, 24 \mathrm{mmol}$ in $3.2 \mathrm{ml}$ of $\mathrm{CH}_{2} \mathrm{Cl}_{2}$ ) were added dropwise at $-60^{\circ} \mathrm{C}$. The reaction was completed in $15 \mathrm{~h}$ in this scale. $\mathrm{H}_{2} \mathrm{O}$ was added for quenching and the product was extracted with ethyl acetate. The combined organic layer was washed with brine, then dried over $\mathrm{Na}_{2} \mathrm{SO}_{4}$. Further purification was performed by flash chromatography on silica gel to afford product $22(6.99 \mathrm{~g}, 100 \%)$. Diastereomeric excess was determined by NMR: ${ }^{1} \mathrm{H}-\mathrm{NMR}\left(\mathrm{CDCl}_{3}\right) \delta: 7.14-7.30$ $(\mathrm{m}, 5 \mathrm{H}), 4.78(\mathrm{~d}, J=7.3 \mathrm{~Hz}, 1 \mathrm{H}), 4.51(\mathrm{~d}, J=3.0 \mathrm{~Hz}, 1 \mathrm{H}), 4.01-4.08(\mathrm{~m}$, $1 \mathrm{H}), 3.00$ (dd, $J=13.9,6.3 \mathrm{~Hz}, 1 \mathrm{H}), 2.75(\mathrm{dd}, J=14.0,8.6 \mathrm{~Hz}, 1 \mathrm{H}), 1.36$ (s, $9 \mathrm{H}), 0.20(\mathrm{~s}, 9 \mathrm{H}) ;{ }^{13} \mathrm{C}-\mathrm{NMR}\left(\mathrm{CDCl}_{3}\right) \delta: 154.9,136.6,128.9,128.6,126.8$, $118.3,80.1,63.0,55.0,35.8,28.3,-0.3$; IR (neat) $v$ : 2225, 1714, $1120 \mathrm{~cm}^{-1}$; MS (EI) $\mathrm{m} / z 349\left(\mathrm{M}^{+}+\mathrm{H}\right)$; high resolution (HR)-MS $\mathrm{m} / z$ Calcd for $\mathrm{C}_{18} \mathrm{H}_{29} \mathrm{~N}_{2} \mathrm{O}_{3} \mathrm{Si} 349.1947$, Found 349.1975; $[\alpha]_{\mathrm{D}}^{25}-70^{\circ}\left(c=2.0, \mathrm{CHCl}_{3}\right)$.

(2R,3S)-3-Amino-2-hydroxy-4-phenylbutanoic Acid Hydrochloride (23) Product 22 was treated with $6 \mathrm{~N} \mathrm{HCl}(50 \mathrm{ml})$ at $60^{\circ} \mathrm{C}$ and the reaction mixture was stirred for $48 \mathrm{~h}$. Then the solution was washed in $\mathrm{CH}_{2} \mathrm{Cl}_{2}$. The aqueous layer was evaporated, followed by recrystallization of the residue from $\mathrm{MeOH}-\mathrm{Et}_{2} \mathrm{O}$ to give $3.47 \mathrm{~g}$ pure 23 (75\% yield). ${ }^{1} \mathrm{H}-\mathrm{NMR}\left(\mathrm{CDCl}_{3}\right) \delta$ : $13.01(\mathrm{brs}, 1 \mathrm{H}), 8.13(\mathrm{brs}, 2 \mathrm{H}), 7.15-7.53(\mathrm{~m}, 5 \mathrm{H}), 3.90(\mathrm{~d}, J=2.7 \mathrm{~Hz}$, $1 \mathrm{H}), 3.59(\mathrm{~m}, 1 \mathrm{H}), 3.02(\mathrm{dd}, J=13.4,5.0 \mathrm{~Hz}, 1 \mathrm{H}), 2.89(\mathrm{dd}, J=13.5,9.5 \mathrm{~Hz}$, $1 \mathrm{H}) ;{ }^{13} \mathrm{C}-\mathrm{NMR}\left(\mathrm{CDCl}_{3}\right) \delta: 172.4,136.0,129.2,128.4,126.8,67.3,53.8$, 35.2; IR (neat) $v: 3379,3130,1730,1594,1491 \mathrm{~cm}^{-1}$; MS (EI) $\mathrm{m} / z 232$ $\left(\mathrm{M}^{+}+\mathrm{H}\right)$; HR-MS $m / z$ Calcd for $\mathrm{C}_{10} \mathrm{H}_{14} \mathrm{ClNO}_{3}$ 231.0662, Found 231.0669; $[\alpha]_{\mathrm{D}}^{24}-10^{\circ}(c=0.5,1 \mathrm{~N} \mathrm{HCl})$.

$(2 R, 3 S)$ - $N$-(tert-Butoxycarbonyl)-3-amino-2-hydroxy-4-phenylbutanoic Acid (24) (Boc) $)_{2} \mathrm{O}(460 \mu \mathrm{l}, 2.00 \mathrm{mmol})$ and $\mathrm{Na}_{2} \mathrm{CO}_{3}(212 \mathrm{mg}$, $2.00 \mathrm{mmol}$ ) were successively added to a solution of $\mathbf{2 3}(232 \mathrm{mg}, 1.00 \mathrm{mmol})$ in dioxane $(2 \mathrm{ml})-10 \% \mathrm{NaOH}(2 \mathrm{ml})$ at $0{ }^{\circ} \mathrm{C}$. The reaction mixture was stirred for $8 \mathrm{~h}$ at room temperature, then neutralized with $1 \mathrm{~N} \mathrm{HCl}$ to $\mathrm{pH} 7$. The water layer was extracted with $\mathrm{CH}_{2} \mathrm{Cl}_{2}$ and the combined organic layer was washed with brine, then dried over $\mathrm{Na}_{2} \mathrm{SO}_{4}$. Further purification was performed by flash chromatography on silica gel to afford the product $\mathbf{2 4}$ as a white solid $(251 \mathrm{mg}, 85 \%) .{ }^{1} \mathrm{H}-\mathrm{NMR}\left(\mathrm{CDCl}_{3}\right) \delta: 7.22-7.30(\mathrm{~m}, 5 \mathrm{H}), 5.00$ $(\mathrm{m}, 1 \mathrm{H}), 4.08-4.22(\mathrm{~m}, 2 \mathrm{H}), 2.94(\mathrm{~m}, 2 \mathrm{H}), 1.37(\mathrm{~s}, 9 \mathrm{H}) ;{ }^{13} \mathrm{C}-\mathrm{NMR}\left(\mathrm{CDCl}_{3}\right)$ $\delta: 174.8,154.8,138.9,129.2,128.1,125.9,78.9,77.8,54.8,37.4,28.2$; IR (neat) $v: 3335,1701 \mathrm{~cm}^{-1}$; MS (EI) $\mathrm{m} / z 278\left(\mathrm{M}^{+}-\mathrm{OH}\right) ; \mathrm{HR}-\mathrm{MS} \mathrm{m} / z$ Calcd for $\mathrm{C}_{15} \mathrm{H}_{20} \mathrm{NO}_{4} 278.1392$, Found 278.1388; $[\alpha]_{\mathrm{D}}^{22}-135^{\circ}\left(c=2.0, \mathrm{CHCl}_{3}\right)$.

(2R,3S)- $\mathrm{N}$-(tert-Butoxycarbonyl)-3-amino-2-hydroxy-4-phenylbutanol (26) $\mathrm{NaBH}_{4}(15 \mathrm{mg}, 0.39 \mathrm{mmol})$ was added to a solution of $25(120 \mathrm{mg}$, $0.388 \mathrm{mmol})$ in $\mathrm{MeOH}(1 \mathrm{ml})$ at $0{ }^{\circ} \mathrm{C}$. After stirring for $30 \mathrm{~min}$ at the same temperature, $\mathrm{LiCl}(17 \mathrm{mg}, 0.39 \mathrm{mmol})$ was added to this suspension. This suspension was gradually warmed to room temperature. After completion of the reaction, saturated $\mathrm{NH}_{4} \mathrm{Cl}$ was added, and most of the $\mathrm{MeOH}$ was removed in vacuo. The residue was carefully extracted with ethyl acetate. The combined organic layer was washed with brine. After removal of the solvent, purification was performed by flash chromatography to give $\mathbf{2 6}(92.5 \mathrm{mg}$, $85 \%)$. Analytical data indicated that this product was identical with the reported compound: ${ }^{1} \mathrm{H}-\mathrm{NMR}\left(\mathrm{CDCl}_{3}\right) \delta: 7.17-7.31(\mathrm{~m}, 5 \mathrm{H}), 4.96(\mathrm{~d}$, $J=8.91 \mathrm{~Hz}, 1 \mathrm{H}), 3.91(\mathrm{~m}, 1 \mathrm{H}), 3.64(\mathrm{~m}, 1 \mathrm{H}), 3.48-3.58(\mathrm{~m}, 2 \mathrm{H}), 3.31(\mathrm{br} \mathrm{s}$,
1H), 3.05 (brs, 1H), 2.89 (d, $J=7.56 \mathrm{~Hz}, 2 \mathrm{H}), 1.39$ (s, 9H); ${ }^{13} \mathrm{C}-\mathrm{NMR}$ $\left(\mathrm{CDCl}_{3}\right) \delta: 156.8,138.0,129.2,128.5,126.4,79.7,71.5,63.9,52.6,38.2$, 28.3; IR (neat) $v: 3355,1692,1521,1173 \mathrm{~cm}^{-1}$; MS (EI) $\mathrm{m} / \mathrm{z} 282\left(\mathrm{M}^{+}+\mathrm{H}\right)$; HR-MS Calcd for $\mathrm{C}_{15} \mathrm{H}_{24} \mathrm{NO}_{4} 282.1705$, Found 282.1708; $[\alpha]_{\mathrm{D}}^{20}-37^{\circ}$ $\left(c=1.0, \mathrm{CHCl}_{3}\right)$.

$(2 R, 3 S)$ - $N$-(tert-Butoxycarbonyl)-3-amino-1,2-eopxy-4-phenylbutane (6) Product $26(30.1 \mathrm{mg}, 0.107 \mathrm{mmol})$ was dissolved in toluene $(1 \mathrm{ml})$. $\mathrm{MsCl}(9 \mu \mathrm{l}, 0.12 \mathrm{mmol})$ and $\mathrm{Et}_{3} \mathrm{~N}(20 \mu \mathrm{l}, 0.143 \mathrm{mmol})$ were added dropwise to the mixture at $0{ }^{\circ} \mathrm{C}$. The mixture was then warmed to room temperature and stirred for $2 \mathrm{~h}$. Saturated $\mathrm{NaHCO}_{3}$ was added to quench and the aqueous layer was extracted with toluene. The combined organic layer was washed with brine. The solvent was evaporated in vacuo and the resulting residue was used for the next step without further purification. Toluene $(2 \mathrm{ml})$ was added to the residue, and $20 \% \mathrm{NaOH}(2 \mathrm{ml})$ was added at $0{ }^{\circ} \mathrm{C}$. The solution was stirred at room temperature until the reaction completed. The reaction mixture was extracted with toluene. The combined organic layer was washed with water, brine, and then dried over $\mathrm{Na}_{2} \mathrm{SO}_{4}$. The crude product was purified by flash chromatography, giving $6(22.5 \mathrm{mg}, 80 \%, 99 \% \mathrm{de})$. Diastereomeric excess was determined by HPLC (column; DAICEL CHIRALCEL OD-H, hexane $/{ }^{i} \mathrm{PhOH} 98 / 2,1 \mathrm{ml} / \mathrm{min}$ ) $t_{\mathrm{R}} 9.1$ and $10.5 \mathrm{~min}$. Analytical data indicated that the product was identical with the reported compound: ${ }^{1} \mathrm{H}-$ NMR $\left(\mathrm{CDCl}_{3}\right) \delta: 7.20-7.33(\mathrm{~m}, 5 \mathrm{H}), 4.49(\mathrm{~m}, 1 \mathrm{H}), 4.12(\mathrm{~m}, 1 \mathrm{H}), 2.84-$ $3.03(\mathrm{~m}, 3 \mathrm{H}), 2.69(\mathrm{~m}, 1 \mathrm{H}), 2.59(\mathrm{~m}, 1 \mathrm{H}), 1.39(\mathrm{~s}, 9 \mathrm{H}) ;{ }^{13} \mathrm{C}-\mathrm{NMR}\left(\mathrm{CDCl}_{3}\right)$ $\delta: 155.4,137.2,129.4,128.5,126.7,79.5,52.6,50.5,44.5,39.8,28.2 ;$ IR (neat) v: 3339, 1685, 1650,1247, $1165 \mathrm{~cm}^{-1}$; MS (EI) $\mathrm{m} / \mathrm{z}: 264\left(\mathrm{M}^{+}+\mathrm{H}\right)$; HR-MS Calcd for $\mathrm{C}_{15} \mathrm{H}_{22} \mathrm{NO}_{3}$ 264.1600, Found 264.1605; $[\alpha]_{\mathrm{D}}^{21}+3^{\circ}$ $\left(c=1.6, \mathrm{CHCl}_{3}\right)$.

2-(4-Formylphenyl)pyridine (8) The flask was charged with $\mathrm{Pd}\left(\mathrm{PPh}_{3}\right)_{4}$ $(77.7 \mathrm{mg}, 76.8 \mu \mathrm{mol})$ and $28(5.00 \mathrm{~g}, 33.3 \mathrm{mmol})$ and then flushed with argon. DME $(55 \mathrm{ml}), 10 \% \mathrm{Na}_{2} \mathrm{CO}_{3}(55 \mathrm{~g}, 53.2 \mathrm{mmol})$, and $27(2.42 \mathrm{ml}$, $25.6 \mathrm{mmol}$ ) were added at room temperature. The mixture was stirred at $80^{\circ} \mathrm{C}$ for $12 \mathrm{~h}$. The product was extracted with toluene and washed with $5 \%$ $\mathrm{NaHCO}_{3}$. The biaryl $\mathbf{8}$ was purified as follows: $\mathbf{8}$ was extracted from the toluene layer with $2 \mathrm{~N} \mathrm{HCl}$, then the aqueous layer was washed with toluene. After neutralization with $10 \% \mathrm{NaOH}, \mathbf{8}$ was extracted with toluene, washed with brine, and dried over $\mathrm{Na}_{2} \mathrm{SO}_{4}$. Concentration gave 8 in $4.33 \mathrm{~g}(92 \%)$, in good agreement with previously reported data: ${ }^{1} \mathrm{H}-\mathrm{NMR}\left(\mathrm{CDCl}_{3}\right) \delta: 10.08$ $(\mathrm{s}, 1 \mathrm{H}), 8.74(\mathrm{dt}, J=4.86,1.35 \mathrm{~Hz}, 1 \mathrm{H}), 8.16-8.24(\mathrm{~m}, 2 \mathrm{H}), 7.96-8.01(\mathrm{~m}$, $2 \mathrm{H}), 7.80-7.82(\mathrm{~m}, 2 \mathrm{H}), 7.31(\mathrm{q}, J=4.59 \mathrm{~Hz}, 1 \mathrm{H}) ;{ }^{13} \mathrm{C}-\mathrm{NMR}\left(\mathrm{CDCl}_{3}\right) \delta$ : $191.8,155.7,149.9,144.8,136.9,136.3,130.1,127.4,123.0,121.1$; IR (KBr) $v: 1712,1573,1550 \mathrm{~cm}^{-1}$; MS (EI) $m / z: 183\left(\mathrm{M}^{+}\right)$; HR-MS Calcd for $\mathrm{C}_{12} \mathrm{H}_{9} \mathrm{NO} 183.0684$, Found 183.0690.

(2R)-2-(3-Chlorophenyl)-2-trimethylsilyloxyacetonitrile (39) The chiral ligand $(560 \mathrm{mg}, 0.784 \mathrm{mmol})$ and $\mathrm{MeP}(\mathrm{O}) \mathrm{Ph}_{2}(644 \mathrm{mg}, 2.98 \mathrm{mmol})$ were placed in a flame-dried flask and dissolved in $14 \mathrm{ml}$ of $\mathrm{CH}_{2} \mathrm{Cl}_{2} . \mathrm{Et}_{2} \mathrm{AlCl}$ $(0.80 \mathrm{ml}, 744 \mu \mathrm{mol}, 0.93 \mathrm{~m}$ in hexane) was added to this solution under argon. The resulting mixture was stirred at room temperature for $1 \mathrm{~h}$ to give a clear solution. Then $\mathbf{3 8}(936 \mu 1,8.27 \mathrm{mmol})$ was added to this solution at $-40^{\circ} \mathrm{C}$. TMSCN $(1.32 \mathrm{ml}, 9.92 \mu \mathrm{mol})$ pre-mixed with $\mathrm{MeOH}(17 \mu \mathrm{l}$, $0.41 \mathrm{mmol}$ ) in $4.0 \mathrm{ml}$ of $\mathrm{CH}_{2} \mathrm{Cl}_{2}$ was slowly added over $8 \mathrm{~h}$. The reaction mixture was stirred for $96 \mathrm{~h}$. Saturated Rochelle salt was added for quenching and the product was extracted with ethyl acetate. The combined organic layer was washed with brine and dried over $\mathrm{Na}_{2} \mathrm{SO}_{4}$. Purification was performed by flash chromatography on $\mathrm{SiO}_{2}$ to afford 39 (1.94 $\mathrm{g}, 98 \%$ yield). ${ }^{1} \mathrm{H}-\mathrm{NMR}\left(\mathrm{CDCl}_{3}\right) \delta: 7.20-7.36(\mathrm{~m}, 4 \mathrm{H}), 5.35(\mathrm{~s}, 1 \mathrm{H}), 0.14(\mathrm{~s}, 9 \mathrm{H}) ;{ }^{13} \mathrm{C}-$ NMR $\left(\mathrm{CDCl}_{3}\right) \delta: 138.0,134.8,130.1,129.4,126.3,124.2,118.6,62.9$, -0.2 ; IR (neat) $v$ : $2244,1111,1083 \mathrm{~cm}^{-1}$; MS (EI) $m / z 239\left(\mathrm{M}^{+}\right)$; HR-MS Calcd for $\mathrm{C}_{11} \mathrm{H}_{14} \mathrm{ClNOSi} 239.0533$, Found 239.0535; $[\alpha]_{\mathrm{D}}^{20}+76^{\circ}(c=2.0$, $\mathrm{CHCl}_{3}$ ). The enantiomeric excess was determined by HPLC after conversion to the ethylcarbonate derivative: ${ }^{1} \mathrm{H}-\mathrm{NMR}\left(\mathrm{CDCl}_{3}\right) \delta: 7.52(\mathrm{~s}, 1 \mathrm{H}), 7.35-$ $7.36(\mathrm{~m}, 3 \mathrm{H}), 6.21(\mathrm{~s}, 1 \mathrm{H}), 4.23-4.34(\mathrm{~m}, 2 \mathrm{H}), 1.34(\mathrm{t}, J=7.16 \mathrm{~Hz}, 3 \mathrm{H})$; ${ }^{13} \mathrm{C}-\mathrm{NMR}\left(\mathrm{CDCl}_{3}\right) \delta: 153.1,135.2,132.9,130.8,130.5,127.8,125.8,115.2$, $65.9,65.5,14.2$; IR (neat) $v: 2256,1759,1248 \mathrm{~cm}^{-1}$; MS (EI) $\mathrm{m} / z 239$ $\left(\mathrm{M}^{+}\right)$; HR-MS Calcd for $\mathrm{C}_{11} \mathrm{H}_{10} \mathrm{ClNO}_{3} 239.0349$, Found 239.0352; $[\alpha]_{\mathrm{D}}^{25}$ $+7^{\circ}\left(c=0.77, \mathrm{CHCl}_{3}\right)(90 \%$ ee). HPLC (DAICEL CHIRALCEL OD-H, hexane $/ \mathrm{PhOH} 95 / 5,0.5 \mathrm{ml} / \mathrm{min}) t_{\mathrm{R}} 18.9$ and $21.3 \mathrm{~min}$.

(2R)-2-(3-Chlorophenyl)-2-hydroxyethylamine Hydrochloride (40) $\mathrm{BH}_{3} \cdot \mathrm{SMe}_{2}(160 \mu \mathrm{l}, 1.68 \mathrm{mmol})$ was added to a solution of $39(98.5 \mathrm{mg}$, $0.41 \mathrm{mmol})$ in THF $(1 \mathrm{ml})$ at an ambient temperature under argon. The reaction mixture was stirred for $4 \mathrm{~h}$ at $60^{\circ} \mathrm{C}$, and then $10 \% \mathrm{NaOH}(1 \mathrm{ml})$ was added to the reaction mixture and the mixture stirred for $30 \mathrm{~min}$ at the same temperature. The separated aqueous layer was extracted with $\mathrm{CH}_{2} \mathrm{Cl}_{2}$ and the combined organic layer was washed with brine and dried over $\mathrm{Na}_{2} \mathrm{SO}_{4}$. The solvent was evaporated in vacuo and $\mathrm{HCl}-\mathrm{MeOH}$ was added to the residue 
at ambient temperature. Removal of excessive $\mathrm{HCl}-\mathrm{MeOH}$ under reduced pressure gave the crystalline $\mathrm{HCl}$ salt $\mathbf{4 0}$, which was recrystallized from MeOH-MTBE to afford 40 (63.6 mg, 75\% yield, 99\% ee). ${ }^{1} \mathrm{H}-\mathrm{NMR}$ $\left(\mathrm{CD}_{3} \mathrm{OD}\right) \delta: 7.48(\mathrm{~s}, 1 \mathrm{H}), 7.29-7.38(\mathrm{~m}, 3 \mathrm{H}), 4.92(\mathrm{dd}, J=12.69,3.24 \mathrm{~Hz}$, $1 \mathrm{H}), 3.18$ (dd, $J=12.69,3.24 \mathrm{~Hz}, 1 \mathrm{H}), 2.98(\mathrm{dd}, J=12.69,9.72 \mathrm{~Hz}, 1 \mathrm{H}) ;{ }^{13} \mathrm{C}-$ NMR $\left(\mathrm{CD}_{3} \mathrm{OD}\right) \delta: 144.7,135.5,131.1,129.1,126.9,125.3,70.1,47.1$; IR (KBr) $v$ : $3353,3006,1600,1522 \mathrm{~cm}^{-1}$; MS (EI) $m / z 172\left(\mathrm{M}^{+}-\mathrm{Cl}\right)$; HR-MS Calcd for $\mathrm{C}_{8} \mathrm{H}_{11} \mathrm{Cl}_{2} \mathrm{NO} 207.0218$, Found 207.0216; $[\alpha]_{\mathrm{D}}^{25}+46^{\circ}(c=1.04,1 \mathrm{~N}$ $\mathrm{HCl})\left(99 \%\right.$ ee). HPLC (DAICEL CROWNPAK CR $(+)$, aq. $\mathrm{HClO}_{4}(\mathrm{pH} 2)$, $0.5 \mathrm{ml} / \mathrm{min}) t_{\mathrm{R}} 18.1$ and $21.5 \mathrm{~min}$.

Procedure for Recovery and Reuse the Bifunctional Ligand 42 After completion of the asymmetric cyanosilylation of benzaldehyde, the reaction was quenched by adding $1 \mathrm{~N} \mathrm{HCl}$. The mixture was stirred vigorously at room temperature for $1 \mathrm{~h}$, then the product was extracted with ethyl acetate. The combined organic layer was washed with brine and dried over $\mathrm{Na}_{2} \mathrm{SO}_{4}$. The solvents were removed in vacuo and diethyl ether was added to the resulting residue. The suspended residue was filtered and washed with diethyl ether to afford ligand $\mathbf{4 2}$. The ligand was purified by recrystallization from $\mathrm{CH}_{2} \mathrm{Cl}_{2}-\mathrm{Et}_{2} \mathrm{O}$ ( $96 \%$ yield).

Procedures for Kinetic Studies Samples for kinetic studies were prepared as followed:

(a) In the Case of the Cyanosilylation in the Absence of the Protic Additive: Well-dried ligand $\mathbf{4 2}(26 \mathrm{mg}, 36.4 \mu \mathrm{mol}), \mathrm{MeP}(\mathrm{O}) \mathrm{Ph}_{2}(29.8 \mathrm{mg}$, $138 \mu \mathrm{mol}$ ), and $0.70 \mathrm{ml}$ of $\mathrm{CD}_{2} \mathrm{Cl}_{2}$ were placed in a dried 5-mm NMR tube. $\mathrm{Et}_{2} \mathrm{AlCl}(38 \mu \mathrm{l}, 35.4 \mu \mathrm{mol}, 0.93 \mathrm{M}$ in hexane) was added under argon atmosphere at room temperature and the mixture was allowed to stand for $1 \mathrm{~h}$. The resulting solution was cooled down to $-40^{\circ} \mathrm{C}$, followed by the addition of benzaldehyde $(39.0 \mu \mathrm{l}, 0.384 \mathrm{mmol})$ and TMSCN $(62 \mu \mathrm{l}, 0.46 \mathrm{mmol})$ in $0.2 \mathrm{ml}$ of $\mathrm{CD}_{2} \mathrm{Cl}_{2}$. The sample was quickly loaded into an NMR machine, then the reaction rate was measured by comparison of the integration ratio between the aldehyde proton and the methine proton of the product.

(b) Cyanosilylation in the Presence of the Protic Additive: A solution of TMSCN $(62 \mu 1,0.46 \mathrm{mmol})$ and $\mathrm{MeOH}(0.80 \mu 1,19.2 \mu \mathrm{mol})$ in $0.2 \mathrm{ml}$ of $\mathrm{CD}_{2} \mathrm{Cl}_{2}$ was used instead of the above mentioned TMSCN solution. These kinetic studies indicated an apparent difference of the initial rates between two the reactions $(\mathrm{a}, \mathrm{b})$ as follows.

$$
\begin{aligned}
& \mathrm{a} ; v_{\mathrm{a}, \text { initial }}=1.26 \times 10^{-2} \\
& \mathrm{~b} ; v_{\mathrm{b} \text {,initial }}=1.80 \times 10^{-2} \\
& k_{\text {additive }} / k_{\mathrm{no} \text {-additive }}=v_{\mathrm{b} \text {,initial }} / v_{\mathrm{a} \text {,initial }} \\
& \quad=1.80 \times 10^{-2} / 1.26 \times 10^{-2}=1.43
\end{aligned}
$$

Acknowledgments We gratefully acknowledge Prof. Miyaura, Hokkaido University, for advice on the synthesis of the biaryl 8. Financial support was provided by CREST, The Japan Science and Technology Corporation (JST), and RFTF of Japan Society for the Promotion of Science.

\section{References and Notes}

1) Stinson S. C., Chem. Eng. News, 79, 45-57 (2001).

2) Stinson S. C., Chem. Eng. News, 79, 79-97 (2001).

3) Rouhi A. M., Chem. Eng. News, 80, 43-50 (2002).

4) Beck G., Synlett, 2002, 837-850 (2002).

5) Noyori R., "Asymmetric Catalysis in Organic Synthesis," John Wiley \& Sons, New York, 1994.

6) "Comprehensive Asymmetric Catalysis," ed. by Jacobsen E. N., Pfaltz A., Yamamoto H., Springer, Berlin, 1999.

7) Ojima I., "Catalytic Asymmetric Synthesis," Wiley-VCH, New York, 2000.

8) Hamashima Y., Sawada D., Kanai M., Shibasaki M., J. Am. Chem. Soc., 121, 2641-2642 (1999).

9) Hamashima Y., Sawada D., Nogami H., Kanai M., Shibasaki M., Tetrahedron, 57, 805-814 (2001).

10) Shibasaki M., Kanai M., Chem. Pharm. Bull., 49, 511—524 (2001).

11) Shibasaki M., Kanai M., Funabashi K., Chem. Commun., 2002, 1989-1999 (2002).

12) Kanai M., Hamashima Y., Shibasaki M., Tetrahedron Lett., 41, 24052409 (2000)

13) Manickam G., Nogami H., Kanai M., Groger H., Shibasaki M., Synlett, 2001, 617-620 (2001).

14) For the synthesis of asymmetric cyanohydrins using chiral catalysts, see ref. $15-20$.

15) Hwang C.-D., Hwang D.-R., Uang B.-J., J. Org. Chem., 63, 67626763 (1998).
16) Belokon' Y. N., Caveda-Cepas S., Green B., Ikonnikov N. S., Khrustalev V. N., Larichev V. S., Moscalenko M. A., North M., Orizu C., Tararov V. I., Tasinazzo M., Timofeeva G. I., Yashkina L. V., J. Am. Chem. Soc., 121, 3968-3973 (1999).

17) Liang S., Bu X. R., J. Org. Chem., 67, 2702-2704 (2002).

18) North M., Synlett, 1993, 807-820 (1993).

19) Effenberger F., Angew. Chem. Int. Ed. Engl., 33, 1555-1564 (1994).

20) Gregory R. J. H., Chem. Rev., 99, 3649-3682 (1999).

21) Takamura M., Hamashima Y., Usuda H., Kanai M., Shibasaki M., Angew. Chem. Int. Ed. Engl., 39, 1650-1652 (2000).

22) Takamura M., Hamashima Y., Usuda H., Kanai M., Shibasaki M., Chem. Pharm. Bull., 48, 1586-1592 (2000).

23) Sawada D., Shibasaki M., Angew. Chem. Int. Ed. Engl., 39, 209-213 (2000).

24) Sawada D., Kanai M., Shibasaki M., J. Am. Chem. Soc., 122, 1052110532 (2000).

25) Funabashi K., Ratni H., Kanai M., Shibasaki M., J. Am. Chem. Soc., 123, 10784-10785 (2001).

26) Yabu K., Masumoto S., Yamasaki S., Hamashima Y., Kanai M., Du W., Curran D. P., Shibasaki M., J. Am. Chem. Soc., 123, 9908-9909 (2001).

27) Takamura M., Funabashi K., Kanai M., Shibasaki M., J. Am. Chem. Soc., 123, 6801-6808 (2001).

28) Takamura M., Yanagisawa H., Kanai M., Shibasaki M., Chem. Pharm. Bull., 50, 1118-1121 (2002).

29) Masumoto S., Suzuki M., Kanai M., Shibasaki M., Tetrahedron Lett., 43, 8647-8651 (2002).

30) Atazanavir is also known by the experimental name BMS-232632 or CGP-73547, see ref. 31-33.

31) Bold G., Fässler A., Capraro H.-G., Cozens R., Klimkait T., Lazdins J., Mestan J., Poncioni B., Rosel J., Stover D., Tintelnot-Blomley M., Acemoglu F., Ucci-Stoll K., Wyss D., Lang M., J. Med. Chem., 41, 3387-3401 (1998).

32) Rabasseda X., Silvestre J., Castaner J., Drugs Fut., 24, 375-380 (1999).

33) Xu Z., Singh J., Schwinden M. D., Zheng B., Kissick T. P., Patel B., Humora M. J., Quiroz F., Dong L., Hsieh D.-M., Heikes J. E., Pudipeddi M., Lindrud M. D., Srivastava S. K., Kronenthal D. R., Mueller R. H., Org. Process Res. Dev., 6, 323-328 (2002).

34) Currier J. S., Havlir D. V., Topics in HIV Medicine, 10, 11-17 (2002).

35) Wilkin T. J., Hay C. M., Hogan C. M., Hammer S. M., Topics in HIV Medicine, 10, 18-35 (2002).

36) We successfully demonstrated the catalytic asymmetric Strecker-type reaction of various $\mathrm{N}$-fluorenyl aldimines in the presence of $9 \mathrm{~mol} \%$ of catalyst $(R)-1$ and $20 \mathrm{~mol} \%$ of $\mathrm{PhOH}$ as a proton source. Pivalaldehyde imine could give the corresponding the D-aminonitrile in $44 \mathrm{~h}$ in $97 \%$ yield with $78 \%$ ee, and then be converted to D-tert-leucine through three steps in high yield and without racemization. L-tert-Leucine was obtained by the same methods as described above, using $9 \mathrm{~mol} \%$ of the catalyst $(S)$-1. L-tert-Leucine was treated with methyl chloroformate and gave the methyl carbamate $\mathbf{4}$ in $80 \%$ yield with $77 \%$ ee, and then enantiomerically pure 4 was produced by recrystallization from ${ }^{i} \mathrm{PrOH}-$-hexane, see ref. 21, 22.

37) Evans B. E., Rittle K. E., Homnick C. F., Springer J. P., Hirshfield J., Veber D. F., J. Org. Chem., 50, 4615-4625 (1985).

38) Luly J. R., Dellaria J. F., Plattner J. J., Soderquist J. L., Yi N., J. Org. Chem., 52, 1487-1492 (1987).

39) Romeo S., Rich D. H., Tetrahedron Lett., 35, 4939-4942 (1994).

40) Ghosh A. K., Fidanze S., J. Org. Chem., 63, 6146-6152 (1998).

41) For selected examples of the synthesis of bestatin or its components, see ref. $42-48$.

42) Suda H., Takita T., Aoyagi T., Umezawa H., J. Antibot., 29, 100-101 (1976).

43) Suda H., Takita T., Aoyagi T., Umezawa H., J. Antibot., 29, 600-601 (1976).

44) Matsuda F., Matsumoto T., Ohsaki M., Ito Y., Terashima S., Chem. Lett., 1990, 723-724 (1990).

45) Matsuda F., Matsumoto T., Ohsaki M., Ito Y., Terashima S., Bull. Chem. Soc. Jpn., 65, 360-365 (1992).

46) Kobayashi Y., Teramoto Y., Kamijo T., Harada H., Ito Y., Terashima S., Tetrahedron, 48, 1853-1868 (1992).

47) Wasserman H. H., Xia M., Petersen A. K., Jorgensen M. R., Curtis E. A., Tetrahedron Lett., 40, 6163-6166 (1999).

48) Bergmeier S. C., Stanchina D. M., J. Org. Chem., 64, 2852-2859 
(1999).

49) Corey E. J., Zhang F.-Y., Angew. Chem. Int. Ed. Engl., 38, 1931-1934 (1999).

50) Parkes K. E. B., Bushnell D. J., Crakett P. H., Dunsdon S. J., Freeman A. C., Gunn M. P., Hopkins R. A., Lambert R. W., Martin J. A., Merrett J. H., Redshaw S., Spurden W. C., Thomas G. J., J. Org. Chem., 59, 3656-3664 (1994).

51) Girijavallabhan V. M., Bennett F., Patel N. M., Ganguly A. K., Dasmahapatra B., Butkiewicz N., Hart A., Bioorg. Med. Chem., 2, 10751083 (1994).

52) For selected examples of the synthesis of HIV protease inhibitors or their components, see ref. $53-56$.

53) Sasai H., Kim W.-S., Suzuki T., Shibasaki M., Mitsuda M., Hasegawa J., Ohashi T., Tetrahedron Lett., 35, 6123-6126 (1994).

54) Shibata N., Katoh T., Terashima S., Tetrahedron Lett., 38, 619-620 (1997).

55) Fässler A., Bold G., Steiner H., Tetrahedron Lett., 39, 4925-4928 (1998).

56) Shibata N., Itoh E., Terashima S., Chem. Pharm. Bull., 46, 733-735 (1998).

57) Reetz M. T., Drewes M. W., Harms K., Reif W., Tetrahedron Lett., 29, 3295-3298 (1988)

58) Reetz M. T., Angew. Chem. Int. Ed. Engl., 30, 1531-1546 (1991).

59) Gu J.-H., Okamoto M., Terada M., Mikami K., Nakai T., Chem. Lett., 1992, 1169-1172 (1992).

60) Ipaktschi J., Heydari A., Chem. Ber, 126, 1905-1912 (1993).

61) Nishizawa R., Saino T., Takita T., Suda H., Aoyagi T., Umezawa H., J. Med. Chem., 20, 510-515 (1977).

62) Andrés J. M., Martinez M. A., Pedrosa R., Pérez-Encabo A., Tetrahedron: Asymmetry, 12, 347-353 (2001).

63) Yuan W., Munoz B., Wong C.-H., Haeggström J. Z., Wetterholm A., Samuelsson B., J. Med. Chem., 36, 211-220 (1993).

64) Munoz B., Giam C.-Z., Wong C.-H., Bioorg. Med. Chem., 2, $1085-$ 1090 (1994).

65) Kang S. H., Ryu D. H., Bioorg. Med. Chem. Lett., 5, 2959-2962 (1995).

66) Hanson G. J., Lindberg T., J. Org. Chem., 50, 5399—5401 (1985).
67) Miyaura N., Suzuki A., Chem. Rev., 95, 2457-2483 (1995).

68) Hassan J., Sevignon M., Gozzi C., Schulz E., Lemaire M., Chem. Rev., 102, 1359-1469 (2002).

69) Kotha S., Lahiri K., Kashinath D., Tetrahedron, 58, 9633-9695 (2002).

70) Indolese A. F., Tetrahedron Lett., 38, 3513-3516 (1997).

71) Saito S., Oh-tani S., Miyaura N., J. Org. Chem., 62, 8024-8030 (1997).

72) Saito S., Sakai M., Miyaura N., Tetrahedron Lett., 37, 2993-2996 (1996).

73) Crociani B., Di Bianca F., Giovenco A., Berton A., J. Organomet. Chem., 323, 123-134 (1987).

74) Mitchell M. B., Wallbank P. J., Tetrahedron Lett., 32, 2273-2276 (1991).

75) Ali N. M., McKillop A., Mitchell M. B., Rebelo R. A., Wallbank P. J., Tetrahedron, 48, 8117-8126 (1992).

76) Littke A. F., Fu G. C., Angew. Chem. Int. Ed. Engl., 41, 4176-4211 (2002).

77) Mathvink R. J., Tolman J. S., Chitty D., Candelore M. R., Cascieri M. A., Colwell L. F., Deng L., Feeney W. P., Forrest M. J., Hom G. J., MacIntyre D. E., Miller R. R., Stearns R. A., Tota L., Wyvratt M. J., Fisher M. H., Weber A. E., J. Med. Chem., 43, 3832-3836 (2000).

78) Emorine L. J., Marullo S., Briend-Sutren M.-M., Patey G., Tate K., Delavier-Klutchko C., Strosberg A. D., Science, 245, 1118-1121 (1989).

79) Kordik C. P., Reitz A. B., J. Med. Chem., 42, 181-201 (1999).

80) When HCN was used as a cyanation reagent, the reaction did not proceed at all. This result suggests that the actual nucleophile is TMSCN, not $\mathrm{HCN}$. MeOH must be immediately converted to MeOTMS and HCN. The formation of MeOTMS was confirmed by NMR.

81) Mai K., Patil G., J. Org. Chem., 51, 3545-3548 (1986).

82) Vachal P., Jacobsen E. N., Org. Lett., 2, 867-870 (2000).

83) Sigman M. S., Vachal P., Jacobsen E. N., Angew. Chem. Int. Ed. Engl., 39, 1279-1281 (2000).

84) Nogami H., Matsunaga S., Kanai M., Shibasaki M., Tetrahedron Lett., 42, 279-283 (2001). 